\title{
SME EMPOWERMENT IN SURABAYA : \\ Case Study Jajan Pasar Association in District Tandes
}

\author{
Berman Surriadi \\ Property Consultant \& Facility Management PT Cushman \& Wakefield \\ Email: bermansuryadi@yahoo.com
}

\begin{abstract}
After the economic crisis hit almost all developing countries in 1997 ago, small and medium enterprises (SMEs) has been demonstrated as a bussiness sector that is able to survive in the storm crisis. The fact is that then able to deflect the direction of governmenteconomic policy. From the pro capitalist becomes more populist. Small and medium enterprisesubsequently deemed to have a strategic role in national economic development. With the flexibility that is owned, SMEs is considered one sector to reduce unemployment and improve people's lives. The purpose of this research to identify the role of state/government,in case regional government (Pemda Tk II) Kotamadya Surabaya, for empowerment UKM Paguyuban jajan Pasar. How the government's efforts to give a space conducive to UKM.
\end{abstract}

Keywords : new institutional economy theory, role, government, empowerment

\section{PEMBERDAYAAN UKM DI KOTA SURABAYA : Studi Kasus Paguyuban Jajan Pasar di KecamatanTandes}

\begin{abstract}
ABSTRAK
Setelah krisis ekonomi melanda hampir semua negara berkembang termasuk Indonesia pada 1997 silam, UKM telah menunjukkan sebagai sektor usaha yang mampu bertahan di tengah badai krisis. Kenyataan inilah yang akhirnya bisa membelokkan arah kebijakan-kebijakan ekonomi pemerintah. Dari yang pro kapitalis menjadi lebih merakyat. UKM selanjutnya dipandang mempunyai peran yang strategis dalam pembangunan ekonomi nasional. Dengan fleksibilitas yang dimiliki UKM dianggap merupakan salah satu sektor riil yang dapat mengurangi tingkat pengangguran dan meningkatk antara hidup masyarakat. Penelitian ini bermaksud mengidentifikasi peran negara/pemerintah, dalam hal ini pemerintah daerah tingkat II Kotamadya Surabaya, terhadap pemberdayaan UKM Paguyuban Jajan pasar.
\end{abstract}

Kata kunci: teori ekonomi kelembagaan baru, peran, pemerintah, pemberdayaan. 


\section{PENDAHULUAN}

Sektor Usaha Kecil Menengah merupakan himpunan dari sektor usaha informal justru lebih tangguh dan tahan uji menghadapi badai krisis moneter yang terjadi. Mudradjad Kuncoro dalam Harian Bisnis Indonesia edisi 21 Oktober 2008 mengemukakan UKM mampu bertahan di tengan badai krisis dikarenakan, pertama tidak mempunyai utang di luar negeri, kedua, tidak mempunyai utang di perbankan karena mereka dianggap unbankable, ketiga menggunakan input lokal tapi outputnya berorientasi ekspor. Sehingga pada akhirnya UKM yang mampu menyelamatkan perekonomian bangsa saat itu.

Kemunculan UKM di Indonesia umumnya berasal dari usaha informal. Hal ini karena selama ini UKM lebih banyak dilakoni oleh mereka yang secara sosial ekonomi dianggap kurang beruntung dengan tingkat pendidikan rendah. Mereka hanya bermodalkan keterampilan yang terbatas. Perkembangan UKM yang pesat dan dilihat dari kenyataan bagaimana UKM mampu bertahan ditengah krisis, UKM diharapkan mampu memberikan kontribusi positif dan signifikan untuk menanggulangi masalah-masalah sosial ekonomi di atas. Selain dianggap sebagai katup penyelamat di tengah krisis UKM juga memberikan kontribusi yang besar terhadap pembentukan PDB (Product Domestik Bruto). Peningkatan kontribusi PDB inilah yang mampu menggerakkan dan memacu percepatan pertumbuhan perekonomian Indonesia.

Dengan memanfaatkan kekayaan dan keragaman budaya lokal (local culture) sebagai input product, UKM jenis ini akan ternyata mampu bersaing baik ditingkat lokal maupun skala nasional. Bahkan beberapa produk bisa menembus pasar ekspor, sehingga bisa menghasilkan pundi-pundi devisa bagi negara. Hal inilah yang kemudian menggugah ketertarikan pemerintah khususnya pemerintah daerah untuk semakin memperhatikan keberadaan UKM. Dengan diberlakukannya otonomi daerah, maka Pemerintah daerah mempunyai kewenangan untuk menentukan sendiri arah kebijakan ekonominya. Pemerintah Daerah, dalam hal ini pemerintah kota atau kabupaten merupakan institusi yang secara langsung bersentuhan dengan aktivitas UKM. Oleh sebab itu pemerintah kota/kabupaten banyak mengeluarkan kebijakan/program yang berguna untuk pemberdayaan UKM.

Surabaya sebagai kota terbesar kedua setelah juga mempunyai permasalahanpermasalahan seperti disebutkan di atas, Surabaya merupakan pusat dari kegiatan ekonomi masyarakat sekitarnya. Beberapa kota sekitar Surabaya yang terkenal dengan sebutan Gerbang Kertasusila (Gresik, Bangkalan, Mojokerto, Surabaya, Sidoarjo dan Lamongan) menjadikan Surabaya sebagai barometer pembangunan dan sebagai tujuan urbanisasi bagi warganya.

Di Surabaya perkembangan dan pertumbuhan UKM dalam 4 tahun terakhir jumlah UKM yang terdaftar di Disperindag mencapai 2 ribu UKM. Dari 2 ribu UKM sudah mampu menyerap lebih dari 20 ribu warga sekitar untuk dijadikan karyawan. Walikota Surabaya Tri Risma Harini mengaku terkejut dengan perkembangan ini. UKM yang semula hanya berekspetasi mengentas kemiskinan bagi dirinya sendiri, kini punya kontribusi yang signifikan terhadap pengentasan kemiskinan dan emngurangi angka pengangguran di daerah. Hal ini karena UKM mampu menyerap jumlah tenaga kerja yang tidak sedikit di lingkungan tempat UKM itu berada. Oleh karena itu pemerintah kota memberi perhatian dan ruang gerak yang kondusif demi perkembangan UKM. Berbagai program diluncurkan sebagai wujud perhatian pemerintah misalnya urban farming, kampung unggulan, kampung perempuan, koperasi serta PKL. Di lokasi tempat penelitian ini dilakukan yaitu di Kecamatan Tandes terdapat banyak UKM. Tapi penelitian ini nanti dibatasi pada UKM paguyuban pembuat dan penjual jajan pasar, salah satu andalan UKM yang ada di Kecamatan Tandes. 
Pemerintah kota melihat potensi yang sangat besar dari UKM Paguyuban Jajan Pasar ini, baik dilihat dari faktor ekonomi, yakni perputaran uang yang mencapai di atas 72 juta perhari dan faktor sosial di mana mereka mampu mengatasi pengangguran dengan menciptakan lapangan kerja, baik untuk dirinya sendiri maupun orang lain. Perhatian pemerintah kota inilah yang nanti akan menjadi inti penelitian.

Pemkot Surabaya berupa program pengentasan kemiskinan sudah bisa mengeliminir permasalahan yang seringkali muncul di tubuh UKM. Sehingga bisa menjadikan UKM ini menjadi satu lembaga yang kuat sebagai wujud kepedulian pemerintah terhadap usaha sektor informal yang pada kenyataannya secara tidak langsung telah banyak membantu pemerintah dalam mengatasi permasalahan-permasalahan sosial ekonomi masyarakat. Selanjutnya peran pemerintah ini nantinya akan dianalisa dengan menggunakan pendekatan (teori) ekonomi kelembagaan baru.

Mencermati sistem ekonomi sebuah negara tidak bisa dilepaskan dari sistem pemerintahan negara tersebut. Karena dua hal tersebut saling berkaitan dan saling mempengaruhi sama lain. Negara sebagai institusi (organisasi/lembaga) pemerintahan mengambil peran penting dalam setiap kebijakan yang menyangkut perekonomian, terutama di tingkat makro ekonomi. Bahkan secara eksplisit Acemaglu dan Robinson (dalam Erani; 2012; 38) menyebutkan bahwa kelembagaan merupakan sumber penting yang menentukan suatu negara/bangsa gagal atau maju perekonomiannya. Demikian juga perekonomian, berpengaruh terhadap kelangsungan hidup suatu bangsa (negara). Ekonomi dianggap sebagai salah satu unsur roda penggerak kehidupan berbangsa dan bernegara. Oleh karena itulah teori ekonomi selalu berkembang seiring dengan perkembangan peradaban umat manusia. Karena pada dasarnya munculnya teori atau pemikiran itu berdasarkan kejadian-kejadian yang dihadapi manusia. Demikianlah Teori atau pemikiran muncul guna menjawab dan menyelesaikan permasalahan yang ada. Sepanjang peradaban manusia sudah muncul teori ekonomi klasik, neoklasik, teori ekonomi kelembagaan lama dan teori ekonomi kelembagaan baru.

Dari beberapa teori tersebut, teori ekonomi kelembagaan baru lah (NIE) yang belakangan banyak diterapkan di beberapa negara. Hal ini karena teori/pendekatan ekonomi kelembagaan baru ini dipandang memiliki pemikiran yang lengkap dan kekinian sehingga bisa menjawab permasalahan-permasalahan ekonomi yang muncul. Berbeda dengan teori ekonomi kelembagaan lama (OIE), yang menentang pemikiran Neoklasik, NIE justru menyempurnakan teori-teori yang dikembangkan oleh neoklasik. Bahasan dalam NIE mencakup 4 hal penting yang akan menjadi bahan kajian dalam penelitian ini yaitu transaction cost, property right, sistem informasi dan role of the game (aturan main).

\section{TINJAUAN PUSTAKA}

\section{Ekonomi kelembagaan Baru}

Ekonomi kelembagaan adalah paradigma baru dalam ilmu ekonomi yang melihat kelembagaan dalam menentukan bagaimana sistem ekonomi dan sosial bekerja, (Black, 2002). Kelembagaan menurut Douglass C North (1996) secara sederhana dapat dipahami sebagi seperangkat aturan yang mengatur hubungan antara aktor dan orgnisasi dalam suatu konteks. Aspek yang penting dalam ekonomi kelembagaan dalam kaitannya untuk menjadikan UKM kuat secara kelembagaan adalah menyangkut property right (hak kepemilikan), transaction cost (biaya transaksi), role of the game yang kondusif dan informasi yang diakses oleh UKM tidak asymetris

1. Property right / hak kepemilikan ini melekat dalam bentuk aturan formal dan juga norma sosial dan adat. Relefansi hak pemilikan ini tergantung dari seberapa besar ia bisa dijalankan dan diakui dalam masyarakat, Brazel (1989). Kaitannya dengan UKM, hak 
kepemilikan ini terartikulasi dalam perijinanan dan hak cipta. Bagaimana kedua instrumen yang sangat penting itu didapat oleh UKM.

2. Biaya transaksi (transaction cost). Seberapa besar biaya yang dikeluarkan UKM dalam mengurus perijinan, pengelolaan produksi dan penjualan, sehingga UKM bisa berkembang tanpa harus diberatkan oleh biaya-biaya transaksi.

3. Role of the game adalah aturan main yang mengawal proses perkembangan UKM

4. Akses informasi yang diterima UKM, kaitannya dengan pemerintah yaitu regulasi ataupun informasi internal dalam pengelolaan UKM.

\section{UKM (Usaha Kecil dan Menengah)}

Ada banyak definisi tentang UKM (Usaha Kecil Menengah). Berikut akan dipaparkan beberapa definisi UKM menurut beberapa tinjauan.

UKM (Usaha Kecil dan Menengah) adalah sebuah istilah yang mengacu ke jenis usaha kecil dengan kekayaan bersih paling banyak Rp 200.000.000,-- tidak termasuk tanah dan bangunan tempat usaha (Instruksi Presiden No.10 tahun 1999). Dan usaha yang berdiri sendiri. Menurut keputusan Presiden RI no. 99 tahun 1998 pengertian Usaha Kecil adalah Kegiatan ekonomi rakyat yang berskala kecil dengan bidang usaha yang secara mayoritas merupakan kegiatan usaha kecil dan perlu dilindungi untuk mencegah persaingan usaha yang tidak sehat.

Sedangkan Badan Pusat Statistik (BPS) memberikan definisi UKM berdasarkan kuantitas tenaga kerja. Usaha Kecil merupakan entitas usaha yang memiliki jumlah tenaga kerja 5 s.d 19 orang. Sedangkan usaha menengah merupakan entitas usaha yang mempunyai tenaga kerja 20 s.d 99. (Muditomo,2012:1).

Menurut KepMenKeu Nomor 316/KMK.016/1994 27 Juni 1994 , usaha kecil didefinikan sebagai perorangan atau badan usaha yang telah melakukan kegiatan usaha yang mempunyai penjualan? omset pertahun setinggitingginya Rp 600.000.000,-- atau aset/aktiva setinggi-tingginya Rp 600.000.000,-- (di luar tanah dan bangunan tempat usaha), yang terdiri dari (1) badab Usaha (Fa, CV, PT dan koperasi) dan (2) perorangan (pengrajin industri rumah tangga, petani, peternak, nelayan, penambang, perambah hutan dan pedagang (barang dan jasa).

Undang-Undang No. 20 Tahun 2008 tentang UMKM, 4 Juli 2004 menyebut Usaha Kecil adalah entitas yang memiliki kriteria sebagai berikut: (1) kekayaan bersih antara Rp 50.000 .000 s.d Rp 500.000.000,-- tidak termasuk tanah dan bangunan tempat usaha. (2) memiliki hasil penjualan tahunan antara Rp $300.000 .000 \quad$ s.d $\quad$ Rp 2.500.000.000,--. Sedangkan usaha menengah adalah yang mempunyai kekayaan Rp 500.000.000,-- s.d Rp 10.000.000.000,- tidak termasuk bangunan tempat usaha. (Arief Rahman, 2008) dalam kutipan (Muditomo, 2012;1).

Sementara Sri Winarni (2006) menyebut Usaha Kecil mempunyai ciri-ciri antara lain: 1. Biasanya berbentuk usaha perorangan dan belum berbadan hukum. 2. Aspek legalitas lemah 3. Struktur organisasi bersifat sederhana dengan pembagian kerja yang tidak baku. 4. Kebanyakan tidak mempunyai laporan keuangan dan tidak melakukan pemisahan antara kekayaan pribadi dan kekayaan perusahaan. 5. Kualitas manajemen rendah dan jarang mempunyai rencana usaha. 6. Sumber utama modal usaha adalah modal pribadi 7. SDM terbatas 8. Pemilik memiliki ikatan batin yang kuat dengan perusahaan, sehingga seluruh kewajiban perusahaan juga menjadi kewajiban pemilik.

Dalam penelitian ini UKM yang dimaksud adalah paguyuban jajan pasar, yaitu UKM yang bergerak dibidang pembuatan dan penjualan kue basah. 


\section{Peranan}

Peranan menurut Soekanto (1990:3), peranan adalah aspek yang dinamis dari kedudukan seseorang dan karena kedudukan itu ia melakukan sesuatu tindakan atau gerak perubahan dinamis di mana dari usaha itu diharapkan akan tercipta suatu keadaan atau hasil yang diinginkan. Tindakan tersebut dijalankan dengan memanfaatkan kewenangan, kekuasaan serta fasilitas yang dimiliki karena kedudukannya.

Peranan pemerintah sebagai agen pembangunan terlibat dalam 5 wujud utama, yaitu pertama, selaku stabilisator, peran pemerintah sebagai stabilisator sangat penting dan harus dimainkan secara efektif. Di bidang ekonomi, pemerintah harus berupaya membangun berbagai sektor ekonomi secara merata guna meningkatkan pendapatan rakyat. Kedua, selaku inovator, pemerintah sebagai keseluruhan harus menjadi sumber dari hal-hal baru. Pemerintah bukan hanya pelaksana kebijakan-kebijakan pembangunan, tapi harus berfungsi sebagai perumus ide-ide pembangunan. Ketiga, selaku modernisator, pemerintah bertugas untuk mengiringi masyarakat ke arah kehidupan yang modern. Keempat, selaku pelopor, pemerintah harus menjadi panutan (role model) bagi masyarakat. Kelima, selaku pelaksana sendiri pemerintah masih dituntut untuk berperan sebagai pelaksana sendiri berbagai kegiatan, menurut Siagian (2012;142-149).

Sementara menurut Tambunan (2002,h.146) peranan pemerintah daerah adalah pertama, implementasi, elaborasi dan koordinasi dari kebijakan KUKM pemerintah pusat. Kedua, formulasi dan implementasi kebijakan oleh pemerintah daerah mengenai pembangunan KUKM, termasuk penyempurnaan administrasi pemerinrah daerah, program dan fasilitasfasilitas finansial serta pendidikan dan pelatihan. Ketiga, koordinasi dan integrasi dari perencanaan, program dan aktivitas-aktivitas pengembangan KUKM. Keempat, peningkatan partisipasi masyarakat daerah dalam kegiatankegiatan KUKM. Kelima, penyiapan laporanlaporan syarat-syarat dan rekomendasirekomendasi terhadap implementasi dari langkah-langkah pemberdayaan KUKM untuk pemerintah pusat dan DPRD.

Hafsah (2004 : 43) melihat peran pemerintah dalam pengembangan UKM adalah pertama, menciptakan iklim usaha yang kondusif. Kedua, bantuan permodalan, dengan menyediakan sistem kredit khusus UKM dengan syarat-syarat administratif yang tidak memberatkan. Ketiga perlindungan usaha, baik melalui undangundang maupun peraturan pemerintah. Keempat, pengembangan kemitraan yang saling membantu antar UKM, UKM dengan pengusaha besar dalam negeri maupun luar negeri. Hal ini dimaksudkan untuk menghindarkan praktek monopoli. Kelima, perlunya pelatihan-pelatihan guna meningkatkan aspek kewirausahaan, baik pelatihan dibidang menejemen dan akuntani, juga pelatihan guna meningkatkan ketrampilan dalam pengembangan bidang usahanya. Keenam, membentuk lembaga khusus yang bisa bertanggung jawab mengkoordinasi semua kegiatan UKM. Ketujuh, memantapkan asosiasi yang telah ada. Kedelapan, mengembangkan promosi atas produk-produk yang dihasilkan dengan media khusus. Kesembilan mengembangkan kerjasama setara. Perlu adanya kerjasama atau koordinasi yang serasi antara pemerintah dengan dunia usaha (UKM)

\section{Pemberdayaan}

Pengertian pemberdayaan menurut UndangUndang Nomor 20 tahun 2008 tentang Usaha Kecil Mikro dan Menengah pasal 1 ayat 8 menyatakan pemberdayaan adalah upaya yang dilakukan pemerintah, dunia usaha dan masyarakat dalam bentuk penumbuhan iklim usaha pembinaan dan pengembangan sehingga usaha kecil mampu menumbuhkan dan memperkuat dirinya menjadi usaha yang sungguh dan mandiri. 
Menurut Suharto (2009:67) pendekatan pemberdayaan dapat dicapai melalui 5p, yaitu: pertama, pemungkinan, menciptakan suasanan atau iklim yang memungkinkan potensi masyarakat berkembang secara optimal. Kedua, penguatan, yakni memperkuat pengetahuan dan kemampuan yang dimiliki masyarakat dalam memecahkan masalah dan memenuhi kebutuhan-kebutuhannya. Ketiga, perlindungan. Yang dimaksud adalah melindungi masyarakat terutama kelompok-kelompok lemah agar tidak tertindas oleh kelompok kuat. Keempat, penyokongan yaitu pemberdayaan harus mampu menyokong masyarakat agar tidak terjatuh ke dalam keadaan dan posisi yang semakin lemah dan terpinggirkan. Kelima, pemeliharaan, yakni memelihara kondisi yang kondusif agar tetap terjadi keseimbangan distribusi kekuasaan antara berbagai kelompok dalam masyarakat.

Kartasasmita (1996), dikutip oleh Nasirin dan Alamsyah (2010:89) menyatakan strategi dalam mengembangakan konsep pemberdayaan masyarakat ada dua. Pertama memberi peluang agar sektor ekonomi dan masyarakat modern dapat tetap maju. Ini karena kemajuan dibutuhkan untuk pembangunan bangsa secara keseluruhan. Kedua, memberdayakan sektor ekonomi dan lapisan rakyat yang masih tertinggal dan hidup di luar atau pinggiran jalur kehidupan modern, melalui 1) menciptakan suasana iklim yang memungkinkan potensi masyarakat berkembang setiap masyarakat memiliki potensi yang dapat dkembangkan. 2) memperkuat daya atau potensi yang dimiliki oleh masyarakat melalui pemberian input berupa bantuan dana, pembangunan secara fisik dan sosial. 3) pengembangan lembaga pendanaan, penelitian dan pemasaran daerah.

Sementara menurut Suryono (2010:262263) menyebutkan ada empat strategi dalam memberdayakan masyarakat, yaitu pertama memberdayakan masyarakat dengan mensosialisasikan peran masyarakat sebagai subyek. Kedua, mendayagunakan mekanisme penyelenggaraan pembangunan atau pemberdayaan masyarakat secara aspiratif, demokratif, efektif dan eisien. Ketiga, mobilisasi sumberdaya manusia seperti tenaga, pikiran dan kemampuan sesuai dengan profesionalismenya. Keempat, memaksimalkan peran pemerintah.

Pemberdayaan sebagai terjemahan kata 'empowerment' adalah membantu klien memperoleh daya untuk mengambil keputusan dan menentukan tindakan yang akan dilakukan yang terkait dengan diri mereka, termasuk mengurangi efek hambatan pribadi dan sosial dalam melakukan tindakan. Hal ini dilakukan dengan peninhgkatan kemampuan dan rasa percaya diri untuk menggunakan daya yang ia miliki antara lain transfer daya dari lingkungan.

\section{METODE PENELITIAN}

Metodologi yang digunakan dalam penelitian ini adalah deskriptif kualitatif, dengan teknik pengumpulan data dilakukan secara direct interview yaitu wawancara langsung dengan teknik purposive sampling yaitu sampel yang diambil didasarkan pada pertimbanganpertimbangan tertentu. Pertimbanganpertimbangan yangdi maksud adalah dengan memilih grup populasi sedemikian rupa sehingga sample yang dipilih mempunyai sifat yang sama dengan populasi. Sample adalahpihak-pihak yang mengetahui dan terkait langsung dengan keberadaan UKM Paguyuban Jajan Pasar. Adapun pihak-pihak yang dimaksud adalah Kepala Seksi Ekonomi Kecamatan Tandes, Kotamadya Surabaya, Kepala Dinas Koperasi Kota Surabaya, Kepala Dinas Perindustrian dan Perdagangan Kota Surabaya, Ketua paguyuban jajan pasar (termasuk Ketua pembuat dan ketua pedagang) dan anggota paguyuban.

Disamping itu, untuk melengkapi data dan mmperkuat analisa penelitian ini menggunakan data sekunder yang dmiliki oleh UKM Paguyuban Jajan Pasar, yakni berupa bukti-bukti administratif yang dibutuhakan. 


\section{HASIL PENELITIAN DAN PEMBAHASAN}

\section{Gambaran Obyek Penelitian}

Bermula dari keinginan menambah penghasilan keluarga, beberapa ibu rumah tangga mencoba berjualan kue basah di dalam lokasi pasar Manukan Lor dan Manukan Kulon. Pada awalnya hanya ada 3 orang ibu yang berjualan. Dengan menggunakan lapak seadanya, karena di dalam pasar memang tidak ada lapak khusus penjual kue. Tidak seperti kios daging atau sayur mayur yang disediakan kios khusus. Mereka menerima penitipan kue basah dari beberapa pembuat yang jumlahnya tidak lebih dari 10 orang.

Kegiatan ini berlangsung beberapa tahun tanpa ada perkembangan berarti. Baru sekitar 10 tahun ke belakang, salah seorang penjual mencoba berjualan di pinggir jalan. Melihat animo pembeli yang bagus, akhirnya beberapa ibu mulai mencoba membuka lapak di pinggir jalan. Mereka buka pagi hari mulai jam set 6 pagi sampai jam 12 siang. Semakin bertambahnya jumlah penjual akhirnya semakin meningkatkan permintaan akan barang dagangan (kue-kue). Akhirnya semakin banyak pula jumlah pembuat kue dengan berbagai macam variasi kue. Dari sinilah awal Paguyuban dibentuk.

Kalau pada awalnya setiap penjual mengantar barang dagangan ke setiap lapak pedagang, maka dengan semakin bertambahnya komunitas ini, mereka sepakat membetuk semacam komunitas, yang akhirnya disebut dengan istilah paguyuban. Maka kemudian disepakati bersama secara konvensi, pembuat tidak perlu mengantar kue-kue produksinya ke para pedagang langsung. Tapi cukup dibawa ke pasar Manukan Lor sebagai 'POSKO' transaksi. Hal ini memudahkan para pembuat karena tidak perlu lagi berkeliling dari satu stand pedagang ke stand pedagang lain. Demikian juga pedagang bisa menemukan berbagai macam kue 'baru' POSKO dan bisa mengenal para pembuat kue yang baru. Sehingga bisa memperbanyak varian kue yang dijual

Seiring berjalannya waktu, komunitas para pembuat dan penjual kue basah tanpa disadari terbentuk. Setiap pukul 4 pagi mereka 'menyebar' hasil produksinya ke para pedagang yang sudah siap memasarkan berbagai macam jenis kue basah yang sudah diproduksi. Setelah bertransaksi, sekitar pukul 5.30 mereka bubar pada kegiatan masing-masing. Siang hari sekitar pukul 13.00, mereka kebali berkumpul untuk mengambil setoran dan sisa dagangan. Masalah baru muncul yaitu 'preman-preman' pasar yang dengan seenaknya melakukan pungutan liar. Karena kebutuhan akan tempat transaksi, maka kondisi tersebut terpaksa diterima. Hal ini berlangsung selama kurun waktu 10 tahun.

Adalah ibu Anik, pembuat sekaligus pedagang (Ketua Paguyuban), mencoba mencari peluang tempat yang lebih bersih dan representatif. Secara kebetulan, pemerintah kota mempunyai program merelokalisir para PKL ke tempat yang lebih bersih dan aman. Maka di setiap kecamatan di bangunlah Sentra Wisata Kuliner guna menampung PKL-PKL yang ada di jalan-jalan. Demikian juga dengan wilayah Kecamatan Tandes, mempunyai beberapa sentra, salah satunya berlokasi di Manukan Lor yang nota bene dekat dengan pasar manukan lor, yang selama ini dipakai POSKO paguyuban jajan pasar. Melihat ada tempat bersih dan belum digunakan, Ibu Anik menemui kepala Sie Perekonomian Kecamatan Tandes untuk diperbolehkan menggunakan tempat tersebut. Rupanya Kasie Perekonomian tertarik dengan aktivitas Paguyuban Jajan Pasar ini. Akhirnya Ibu Anik diperkenalkan dengan Bapak Mahmud, anggota DPRD sekaligus penasehat Sentra Wisata Kuliner.

Singkat cerita sejak Desember 2014, Paguyuban Jajan Pasar mulai bisa bertransaksi di Sentra Wisata Kuliner Manukan Lor. Dengan meknisme yang sama dengan tempat sebelumnya. Dari sinilah awal pemberdayaan Paguyuban jajan Pasar dimulai. 
Paguyuban jajan Pasar saat ini mempunyai anggota 117 orang, dengan perincian 80 orang sebagai pembuat dan 37 sebagai pedagang (penjual). Semua anggota Paguyuban bertempat tinggal di wilayah Kecamatan Tandes, Surabaya Barat. Adapun jangkauan penjualan, saat ini sudah sampai ke wilayah surabaya selatan, surabaya pusat bahkan sampai ke Kabupaten Gresik. Dengan asumsi setiap pembuat membuat minimal 2 macam kue yang masingmasing kue diproduksi sejumlah 300 kue (Tiap pedagang mendapat 10 kue), jadi total 600 kue dikalikan 80 dikalikan harga kue rata-rata 1500, maka uang yang beredar setiap harinya tidak kurang dari Rp 72 juta rupiah.

\section{Upaya-upaya Pemberdayaan Pendampingan Oleh Pemkot Surabaya}

dan

Belum genap setahun sejak kepindahan tempat transaksi dari pasar Manukan Lor ke Sentra Wisata Kuliner Manukan Lor, banyak perkembangan menuju kearah yang lebih baik yang bisa dirasakan oleh para anggota Paguyuban Jajan Pasar ini.

Pertama, Secara organisasi, mereka merasa menjadi lebih "modern", rapi dan teratur. Yang dimaksud adalah, iuran yang disetor ke Ketua Paguyuban bisa dipertanggungjawabkan. Berbeda dengan sebelumnya di mana iuran masuk ke preman pasar yang tentu tidak bisa dipertanggungjawabkan secara administratif. Terlebih setelah itu diadakan pemilihan pengurus baru oleh anggota. Kepengurusan baru ini mendapat legitimasi dari anggota Paguyuban sehingga program-program yang direncanakan dapat diterima dan dilaksanakan.

Kedua, setelah mendapat banyak pengarahan dari Kecamatan, selaku pelaksana dari kebijakan pemerintah kota, penampilan fisik para pembuat dan pedagang kue yang lebih didominasi ibu-ibu lebih rapi. Hal semacam ini sebelumnya dianggap sepele. Membuka wawasan tentang hal ini memang tidak gampang. Mengubah sikap dan gaya tampilan dari yang 'apa adanya' menjadi 'ada apanya' tidak lah mudah. Padahal penampilan mereka terutama para pedagangnya sangat berpengaruh terhadap hasil penjualan. Terutama mereka yang berdagang di kawasan perumahan Elite. Kerapian dan kebersihan meski bukan yang utama, tapi bisa menjadi kunci pembuka pengunjung memperhatikan dagangan kita.

Ketiga, 25 anggota, mulai digandeng untuk mengikuti pelatihan-pelatihan yang diadakan Pemkot Surabaya yang bekerja sama dengan PT Bogasari dan dengan Disperindag (Dinas Perindustrian dan Perdagangan). Pemkot Surabaya bekerjasama dengan PT Bogasari memberikan pelatihan cara membuat berbagai jenis kue yang sebelumnya belum pernah didapat. Ini adalah pengetahuan baru yang sangat bermanfaat, ini bisa menambah varian kue yang dijual. Di samping itu sebagai wujud kepeduliannya, PT Bogasari memberikan locker kepada setiap anggota yang dtempatkan di area sentra wisata kuliner, tempat transaksi.

Sementara itu, Disperindag memberi pelatihan pengetahuan akuntansi dan menejemen. Hal ini dipandang sangat perlu karena banyak dari para anggota Paguyuban Jajan Pasar (terutama para pembuatnya) tidak pernah melakukan catat mencatat atas aktivitas 'produksi' yang mereka lakukan. Di samping dianggap 'merepotkan, pengetahuan semacam itu awam bagi pelaku UKM yang rata-rata adalah ibu rumah tangga. Disperindag juga sudah mengeluarkan SIUP (Surat Izin Usaha dan Perdagangan) bagi 25 orang pembuat jajan pasar. Pembinaan ini sifatnya bertahap. Dari 80 pembuat jajan pasar dan 37 penjual, tahap pertama 25 orang. Hal ini karena peserta pelatihan bukan hanya dari UKM Paguyuban Jajan Pasar saja, tapi UKM se-kotamadya Surabaya. Disperindang juga mengeluarkan izin PIRT(Pangan Industri Rumah Tangga). Di samping dua surat ijin tersebut, sertifikat Halal juga sudah mereka kantongi. Dengan dimilikinya 3 sertifikat tersebut, peguyuban jajan pasar menempatkan dirinya berbeda dengan pedagang dan pembuat jajan pasar di 
tempat lain. Di Pasar Kembang misalnya, yang juga dikenal sebagai pusatnya jajan pasa di kota Surabaya. kondisinya tidak seperti ini. Mereka memakai sistem beli putus. Tidak ada interaksi khusus yang terorganisir antara pembuat dan pedagang. Selain itu beberapa merk produksi mereka sudah dipantenkan ke Departemen Kehakiman. Dengan demikian mereka akan bersaha menjaga mutu dan kualitas produksinya. Pelatihan lain yang diberikan Disperindag adalah pengenalan tentang IT. Mereka diajari membuat website dan email. Ini bekal bagi mereka untuk berjualan di dunia maya secara online. Karena di era serba digital seperti saat ini hampir mustahil jika sesorang tidak mempunyai gadget. Dengan memanfaat gadget yang dimiliki memudahkan mereka untuk bertransaksi baik secara offline maupun online.

Kempat, oleh pemerintah kota, anggotapaguyuban diajak mengikuti Pameranpameran yang diadakan pemkot. Di samping mengadakan pameran khusus buat UKM, mereka juga sering diundang untuk mengikuti bazaar jika Pemkot mengadakan acara secara massal dan terbuka.

Kelima, program pemkot untuk Paguyuban jajan Pasar berikutnya adalah studi banding ke Kampung Unggulan yang tersebar di wilayah kota Surabaya. Hal ini dimaksudkan untuk memberi motivasi kepada anggota Paguyuban agar mereka lebih semangat untuk bergerak maju mempromosikan produksinya dan menjaga kualitas produksi agar bisa bersaing d pasar bebas. 10 kampung unggulan ini sudah di bina Pemkot sejak 2010, bahkan sudah mampu bersaing di pasar ekspor.

Keenam, mengikursertakan dalam pemilihan Pahlawan Ekonomi yang diagendakan pemkot Surabaya setiap tahunnya. Sasaran dari pemilihan Pahlawan Ekonomi ini adalah Ibuibu. Dan ini jelas memunculkan antusiasme bagi Paguyuban Jajan Pasar yang memang sejak awal didominasi kaum Ibu. Selanjutnya yang terpilih sebagai Pahlawan Ekonomi akan diikutsertakan dalam pelatihan-pelatihan yang dipusatkan di
Kapas Krampung Plaza (KAZA). Mulai pelatihan produk sampe kemasan dan pemasaran bisa mereka dapatkan.

Program-program pemerintah tersebut membawa dampak yang cukup signifikan dalam perkembangan UKM Paguyuban Jajan Pasar. Baik intern maupun ekstern. Secara Intern, paguyuban ini menjadi semakin kuat dan solid. Setiap informasi bisa mereka akses dengan cepat. Bila ada anggota yang masuk maupun keluar mereka dengan cepat dapat mengetahuinya. Secara ekstern mereka lebih percaya diri mempromosikan produksinya karena keberadaan mereka sebagai UKM sudah banyak dkenal.

\section{Analisa Data}

Memasuki bagian ini, akan cari keterkaitan dari teori ekonomi kelembagaan baru dengan upayaupaya yang sudah dilakukan Pemkot Surabaya sebagai implementasi peran pemkot dalam pemberdayaan UKM Paguyuban Jajan Pasar.

Menurut pandangan Teori Ekonomi Kelembagaan, UKM dipandang kuat secara kelembagaan jika memenuhi prinsip-prinsip:

\section{Role of game (aturan main)}

Dalam pandangan kelembagaan, Davis and North membedakan aturan main (role of game) dalam institutional environment dan institutional arrangement. Institutional environment terbagi menjadi dua yakni aturan formal dan informal. Aturan formal yang dimaksud adalah aturan yang dikeluarkan pemerintah berupa kebijakankebijakan baik itu undang-undang atau peraturan pemerintah. Sementara aturan informal adalah aturan yang menunjuk pada norma adat istiadat dan sejenisnya.

Dalam kaitannya dengan penelitian ini, aturan formal adalah role of game yang menjadi perhatian utama, karena penelitian ini memang menyoroti peran pemerintah dalam upaya pemberdayaan UKM. 
Selanjutnya, bagaimana memandang aturanaturan yang tersebut di atas bisa memberikan kontribusi yang positif bagi perkembangan UKM. Jika dilihat dan dicermati, sebenarnya pemerintah pusat telah memberi ruang gerak yang cukup bagi perkembangan UKM, yakni dengan dibentuknya kementrian yang membawahi langsung UKM, sehingga diharapkan dapat lebih bisa terkonsentrasi dalam upaya pengembangan UKM yaitu kementrian Koperasi dan UKM. Di mana kebijakankebijakan yang digulirkan pun secara tidak langsung memperhatikan dan fokus terhadap perkembangan UKM.

Namun, sebagaimana diketahui bahwa sistem perekonomian dan kewenangan negara kita juga menganut sistem desentralisasi atau otonomi daerah di mana daerah-daerah diberi kewenangan yang sangat luas untuk mengembangkan potensi ekonomi daerah masing-masing di mana secara tidak langsung pemerintah daerah diberi kewenangan mengeluarkan kebijakan sesuai dengan 'kebutuhannya' masing-masing.

Kebijakan pemerintah berupa regulasi diwujudkan dengan melibatkan instansi terkait seperti kemetrian Koperasi, departemen perindustrian dan perdagangan, kementrian keuangan. Wujud kebijakan yang nyata-nyata berpihak terhadap perkembangan UKM adalah SK Menteri Keuangan (Menkeu) No. 316/KMK.016/1994. SK tersebut mewajibkan Badan Usaha Milik Negara (BUMN) untuk menyisihkan 1-5\% laba perusahaan bagi Pembinaan Usaha Kecil dan Koperasi (PUKK). Selain itu pemerintah telah mengeluarkan tiga butir kebijakan pokok di bidang ekonomi khususnya terkait dengan keberadaan UKM, yaitu :

Pertama, peningkatan jasa layanan keuangan kususnya untuk pelaku UKM, yang meliputi perbaikan layanan jasa perbankan, pasar modal, multifinace dan asuransi.

Kedua, peningkatan infrastruktur layanan jasa keuangan, berupa akses pasar, layanan penagihan dan pembayaran, kemudahan investasi dan menabung serta dukungan umum atas pelaksanaan transaksi perdagangan.

Ketiga adalah meningkatkan kemampuan dan penguasaan aspek-aspek teknis dan manajemen usaha, pengembangan produk dan penjualan, administrasi keuangan dan kewirausahaan secara menyeluruh.

Sementara itu di tingkat pemerintah daerah, kebijakan yang dikeluarkan umumnya merupakan pengejahwantahan atas kebijakan pemerintah pusat, dengan penyesuaian terhadap kondisi lapangan yang ada. Dalam hal ini pemerintah daerah umumnya menggandeng pihak swasta guna 'membesarkan' UKM yang ada di wilayahnya.

Dalam penelitian ini, Pemerintah Kota Surabaya sebagai institusi daerah dipandang sudah cukup kooperatif dalam upaya pemberdayaan UKM. Banyak program-program pro UKM yang telah diluncurkan. Dengan menggandeng PT Bogasari, keduanya rajin memberikan pelatihan-pelatihan bagi UKMUKM yang berbasis kuliner.

Demikian juga kerjasamanya dengan instansi terkait, yaitu Disperindag dan koperasi, memberikan pembinaan dan pemahaman seputar permasalahan adimistrasi manajemen dan akuntasi. Di bidang permodalan, pemerintah daerah bekerja sama dengan Bank-bank pemerintah mengeluarkan program Kredit Usaha Rakyat Kredit Mikro tanpa Agunan dan lain sebagainya.

\section{Property Right (Hak Kepemilikan)}

Hak kepemilikan dalam hal ini terartikulasi dalam bentuk perizinan usaha dan hak cipta yang dihasilkan oleh UKM. Perolehan data menyebutkan bahwa dari 107 anggota paguyuban sudah sekitar 25 anggota yang telah mendapatkan SIUP (Surat Izin Usaha dan Perdagangan, PIRT (Izin Pangan Industri Rumah Tangga) dan Sertifikat Halal untuk produk makanan yang dihasilkan serta Paten 
Merk/Hak Cipta untuk beberapa merk yang sudah dikeluarkan. Hak Cipta bisa atau yang biasa disebut Intellectual Property Right

\section{Kemudahan Mengakses Informasi}

Informasi yang dimaksud adalah tentang kebijakan pemerintah terkait dengan UKM secara khusus atau kebijakan regulasi secara menyeluruh. Untuk memudahkan akses informasi, pemerintah mempunyai situs resmi yang bisa diakses siapa saja. Situs ini berisi program-program dan kebijakan-kebijakan pemerintah, tak terkecuali kebijakan tentang UKM. Selain itu, pemerintah meminta level pemerintahan paling bawah untuk bisa mendampingi setiap kegiatan UKM dan bisa menjadi jembatan bagi UKM dengan pemerintahan yang lebih tinggi.

Koordinasi yang kuat antar lembaga pemerintahan juga memudahkan akses informasi sampai kepada pelaku UKM. Untuk Paguyuban Jajan pasar sendiri, pendampingan dilakukan oleh Kasie perekonomian Kecamatan yang bisa menjadi motivator dan menjadi jembatan arus informasi dari pemerintah ke Paguyuban Jajan Pasar.

\section{Transaction Cost (Biaya Transaksi)}

Biaya transaksi lazim digunakan sebagai alat ukur untuk mengukur efisien tidaknya sebuah desain kelembagaan. Biaya transaksi adalah biaya yang muncul karena negosiasi, mengukur dan memaksakan pertukaran. Dalam kasus UKM ini, biaya transaksi mengarah kepada biaya yang harus dikeluarkan dalam 1) mengurus perijinan, 2) pengelolaan produksi dan 3) penjualan.

\section{1) Pengurusan Periijinan}

Pemerintah kota Surabaya, sebagai obyek penelitian, menunjukkan fakta perannya yang signifikan sehingga bisa menekan biaya transaksi yang dikeluarkan oleh pelaku UKM. Hal ini bisa kita lihat bagaimana pemerintah kota mempermudah birokrasi pengurusan perijinan, SIUP dan PIRT sebagai wujud upaya pemberi.

\section{2) Pengelolaan Produksi}

Biaya yang dimaksud adalah biaya yang dikeluarkan selama proses produksi secara menyeluruh. Kerjasama dengan menggandeng pihak swasta bisa menekan biaya transaksi pada poin ini. Adalah PT Bogasari yang digandeng sebagai mitra guna memberdayaan UKM, khususnya UKM Paguyuban jajan Pasar adalah kebijakan yang boleh dibilang tepat sasaran.

Hal ini karena PT Bogasari sebagai produsen bahan baku UKM Paguyuban Jajan Pasar, mempunyai banyak informasi seputar proses produksi. Mulai dari pengadaan bahan baku, proses pembuatan makanan, cara mengemas produk sampai cara memasarkan semua bisa didapat dengan mengikuti pelatihanpelatihan yang diselenggarakan Pemerintah Kota yang bekerja sama dengan PT Bogasari.

\section{3) Penjualan}

Penjualan adalah proses melempar produk ke pasar. mulai dari tahap promosi sampai produk diterima dan dikonsumsi masyarakat. Peran aktif pemerintah dalam upaya memperkenalkan hasil produksi UKM dengan seringnya mengadakan pameran-pameran di Mall dan sering menyelenggarakan even-even yang diadakan pemerintah .

Penyediaan ruang pameran khusus bagi UKM adalah juga wujud peran pemerintah dalam upaya mempromosikan dan memperkenalkan produk-produk UKM untuk bisa dikenal masyarakat secara lebih luas, baik regional nasional bahkan internasional. Berikutnya adalahpenyediaan sarana dan prasarana yang bisa digunakan oleh Paguyuban Jajan Pasar yaitu Sentra Wisata Kuliner, yang djadikan sebagai tempat berkumpulnya anggota paguyuban dalam bertransaksi adalah wujud lain peran serta pemerintah. Karena dengan 
tersentralnya tempat bertransaksi, segala macam informasi lebih cepat sampai.

Baik itu mengenai kebijakan pemerintah, atau informasi intern, misalnya ada anggota baru yang masuk atau jika ada anggota yang keluar. Bahkan lebih dari itu, jika ada komplain dari konsumen terhadap produk yang dijual bisa langsung disampaikan.

\section{SIMPULAN}

1. UKM lebih mampu bertahan di tengah badai krisis ekonomi dibandingkan dengan perusahaan-perusahaan besar. Keberadaan UKM, yang notabene tercatat anggotanya kebanyakan bergerak di sektor informal setelah begitu banyak perusahaan yang jatuh akibat krisis karena ketidakmampuan membayar hutang, pemerintah mulai melirik keberadaan sektor usaha kecil menengah (UKM).

2. Sistem otonomi daerah dan desentralisasi membuka ruang yang lebih leluasa bagi Pemerintah Kota Surabaya untuk mengusung pemberdayaan UKM seperti Kampung unggulan, pahlawan ekonomi, pembukaan sentra wisata kuliner di tiap kecamatan, pendampingan UKM-UKM ditiap wilayah kecamatan, bekerjasama dengan dinas terkait serta bekerja sama dengan pihak swasta.

3. Peran pemerintah dalam upaya pemberdayaan UKM ditinjau dari kajian teori ekonomi Kelembagaan Baru mengacu pada empat pendekatan: (1) Role of the game, yakni di mana aturan-aturan/kebijakan-kebijakan pemerintah memberi kontribusi yang positif bagi perkembangan UKM (2) Property right (hak kepemilikan) yang terartikulasi dalam kemudahan penerbitan SIUP, PIRT, Hak Cipta. (3) Informasi yang diakses UKM mendekati sempurna, artinya tidak terjadi asimetris informasi. Pemerintah dalam hal ini Kota Surabaya sudah membuat web yang memungkinkan setiap elemen masyarakat mengakses semua kegiatan dan program dari pemerintah kota surabaya dan pendampingan oleh kecamatan kepada setiap UKM semakin memudahkan dan mempercepat akses informasi yang mengalir dari pemerintah ke UKM. (4) Biaya transaksi (transaction Cost) yaitu biaya yang dikeluarkan guna mengurus perijinan, pengelolaan produksi dan penjualan.

Namun terdapat beberapa kelemahan UKM Paguyuban jajan pasar ini, yaitu Paguyuban ini tidak terlembaga secara formal.

a. Tiap-tiap anggota otomatis juga tidak terikat secara formal. Sehingga mereka dengan leluasa keluar masuk menjadi anggota, asal memberi laporan.

b. Hubungan tidak didasarkan pada komitmen mematuhi peraturan, tapi lebih pada 'like' and 'dislike'

c. Perkembangan secara organisasi tidak ada (jalan di tempat). Karena arah dan tujuan juga tidak punya sebagaimana organisasi formal yang melembaga.

d. Rentan akan masalah-masalah yang bisa mengakibatkan perpecahan bahkan pembubaran karena tidak ada landasan kuat baik secara AD/ART maupun secara hukum. 


\section{DAFTAR PUSTAKA}

Bulkin, Farchan, 1984 : Kapitalisme Golongan Menengah dan Negara, Prisma, No 2 th XIII

Nasirin, Chairun dan Alamsyah, 2010, Pemberdayaan Masyarakat dalam Prspektif Good Governance, Malang: Indo Press

Pamudji,S, 1995: Pembinaan Perkotaan di Indonesia, Jakarta: Bina Aksara

Republik Indonesia, 2008, Undang-Undang No 20 tahun 2008 tentang Usaha Mikro, Kecil dan Menengah, Jakarta: Sekretaris Negara

Siagian, P. Sondang, 2012, Administrasi Pembangunan; Konsep Dimensi dan Strateginya; Jakarta: PT Bumi Aksara

Singarimbun, Masri \& Sofian Efendi, 1985 : Metode Penelitian Survey, Jakarta: LP3ES

Soerjono, soekanto, 1990. Sosiologi Suatu pengantar. Jakarta: PT. Rajawali

Suhardjono, 2003. Manajemen Perkreditan Usaha Kecil dan Menengah, Yogyakarta: BPFE

Suharto, Edi, 2010, Membangun Masyarakat Memberdayakan Rakyat, Bandung: PT. Retifika Aditama

Tambunan, 2002, UKM di Indosesia. Beberapa Isu Penting, Jakarta: Salemba Empat

Tan, Meely G, 1990: Masalah-Masalah Penelitian Dalam Koentjoroningrat, Metode Penelitian Masyarakat, Jakarta: PT Gramedia

Winarni, Sri, 2006, Strategi Pengembangan Usaha Kecil Melalui Peningkatan Aksesibilitas Kredit Perbankan. Infokop No 29 Tahun XXII,2006

Yustika, Ahmad Erani, 2013 : Ekonomi Kelembagaan: Paradigma, Teori dan Kebijakan, Jakarta: Erlangga. 